This work is licensed under a Creative Commons Attribution 4.0 International License.

Ovaj rad dostupan je za upotrebu pod međunarodnom licencom Creative Commons Attribution 4.0.

https://doi.org/10.31820/f.31.1.7

Borana Morić-Mohorovičić

\title{
NEKOLIKO NAPOMENA O SINTAKSI DRAGUTINA ANTUNA PARČIĆA U GRAMMATICI DELLA LINGUA SLAVA (ILLIRICA)*
}

dr.sc.Borana Morić-Mohorovičić, Filozofski fakultet, bmoric@ffri.hr, Rijeka

izvorni znanstveni članak

UDK 811.163.42'367

811.163.42-05Parčić, D. A.

rukopis primljen: 1. svibnja 2019.; prihvaćen za tisak: 31. svibnja 2019.

U radu se prikazuju i komentiraju sintaktičke napomene koje Dragutin Antun Parčić zapisuje u Slaganju, prvom dijelu sintakse u Grammatici della lingua slava (illirica) (1873, $\left.{ }^{2} 1878\right)$. Parčićev se sintaktički nauk uspoređuje s Veberovim u djelima Skladnja ilirskoga jezika (1859) i Slovnica hèrvatska za srednja učilišta (1871).

Ključne riječi: Dragutin Antun Parčić; Adolfo Veber; sintaksa; 19. stoljeće

Grammatica della lingua slava (illirica) ${ }^{1}$ Dragutina Antuna Parčića gramatika je hrvatskoga jezika pisana talijanskim, jezikom koji je u (službenoj) uporabi u Dalmaciji, gdje je Parčić proveo najveći dio života, bio čitavo 19. stoljeće 2 .

* Ovaj rad je sufinanciralo Sveučilište u Rijeci projektom uniri-human-18-285.

Rad je rezultat istraživanja u rukopisnoj disertaciji Gramatičar Dragutin Antun Parčić, 2014.

1 U daljnjem tekstu: Grammatica.

2 Hrvatski je jezik status službenoga u Dalmaciji dobio 1883. godine. Narodna je stranka osvojila vlast u većini Dalmacije, a Zadar je pritom ostao oazom talijanaša sve do 1916. godine kada je hrvatski jezik potpuno zamijenio talijanski. O ovoj temi v. npr. Novak 1966. 
Objavljena je 1873. godine $\mathrm{e}^{3}$ u Zadru u izdanju braće Battara, iste godine kada izlazi i treće izdanje Veberove Slovnice hrvatske za srednja učilišta ${ }^{4}$. Drugo popravljeno izdanje tiskano je pet godina kasnije.

Da je „dragi autor (Dragutin Antun Parčić, op. B. M. M.)” u djelo unio „važne novosti /.../ kao i zasluge unapređenja jezika i norme u razinama za učenje” zbog čega će ovo izdanje „najviše cijeniti učenjaci” ${ }^{5}$ saznajemo u pismu čitatelju zadarskoga izdavača Spiridione Artale koje prethodi drugome izdanju iz 1878. godine. Suprotno izdavačkoj napomeni, komparativnom je analizom utvrđeno da se izdanja gramatike iz 1873. i 1878. godine tek neznatno razlikuju. ${ }^{6}$

Iz predgovora doznajemo da je Parčić svoje djelo namijenio učenjacima koji će u gramatici pronaći mnoštvo idioma koji nisu ujednačeni „u govoru ljudi koji žive od Dunava do Jadrana preko Raše i Bojane”" te učenicima „koji zbog zakonskih posljedica moraju završiti školu na jednom (talijanskom, op. B. M. M.) i na drugom (hrvatskom, op. B. M. M.) jeziku"8. Takvim je postupkom autor pokazao da je svjestan jezične raznolikosti na užem slavenskom

3 Predgovor je napisan 4. studenoga 1873. u Zadru pa možemo zaključiti da je Parčićeva gramatika otisnuta potkraj 1873. godine.

4 Treće se izdanje Veberove gramatike iz 1876. od dvaju ranijih izdanja (iz 1871. te 1873. godine) razlikuje „tek slovopisno - umjesto rogatoga e, umjesto ě, Veber piše u dugom slogu ie, a u kratkom je /.../; umjesto èr piše $r$ bez popratnoga mukloga è" (Ham 2006: 94), pa je naslov prvih dvaju izdanja Slovnica hèrvatska za srednja učilišta.

U daljenjem tekstu: Slovnica.

5 „Il favorevole esito col quale fu accolta la prima edizione di questa Grammatica, che ebbe l'onore di una traduzione francese /.../. Le importanti innovazioni introdotte dall'egregio autore, tanto in merito ai progressi della lingua, quanto in quello delle norme volute dai piani d'insegnamento, mi fanno sicuro che la presente edizione incontrerà maggiormente il favore degli studiosi" (Parčić 1878: I).

6 Usp. Morić-Mohorovičić 2014.

U ovome se radu služimo drugim izdanjem Parčićeve Grammatice iz 1878. godine. Bude li bilo navedeno što iz prvoga izdanja, to će biti posebno naglašeno.

7 „in parla dai popoli stanziati tra il Danubio e l'Adriatico, tra l'Arsa e la Bojana” (Parčić 1878: V).

8 „che per legittima conseguenza dovesse completare gli studi lessicografici nell' una e nell' altra lingua" (Parčić 1878: V).

U lipnju 1842. vlada je u Trstu donijela odredbu prema kojoj se u Primorju nastava ima držati na materinskome jeziku. Onu djecu koja žele pohađati gimnaziju učitelji moraju podučiti njemačkome ili talijanskome jeziku, ovisno o školi koju kane upisati. O ovoj temi v. npr. Bolonić - Žic-Rokov 1977. 
području koji spominje, ali i teškoća pred kojima se nađu učenici koji se školuju na talijanskom jeziku te često ne vladaju dobro materinskim jezikom.

Zbog razlike u hrvatskom i talijanskom jeziku autor upozorava da su opis glagola te sintaktički opis različiti od svih dotadašnjih gramatika. „Kod kompliciranijega nastojao sam potražiti i riješiti glavne poteškoće koje bi se mogle pojaviti kod Talijana, s ponuđenim odgovarajućim primjerima prevedenim na oba jezika" , nastavlja dalje autor te tako objašnjava načela po kojima je pisao svoje djelo.

Upravo je njegova praksa lektora-učitelja ${ }^{10}$ pomogla da gramatiku napiše pregledno, jasno i jezgrovito, zbog čega je Veber preporuča za školsku uporabu.

Gramatika je, drži Parčić, skup „pravila za dobro govorenje i pravilno korištenje nekog jezika"11, a dijeli se na rječoslovje i skladnju. Rječoslovje obuhvaća glasoslovje, likoslovje te tvorenje rieči. ${ }^{12}$ Skladnja obuhvaća sedamdesetak stranica (str. 129-201), čime Parčić pripada malobrojnim starijim "gramatičarima koji pokušavaju sustavno proučiti i predstaviti hrvatsku sintaksu" (Stolac - Vlastelić 2005: 3). ${ }^{13}$ Kao i u ostalih jezičnih razina, Parčić se i u sintaktičkome dijelu oslanja na znanja koja su njegovi učenici usvojili u talijanskoj gramatici. Iščitavamo to i primjerice iz njegove napomene: „U ovom ćemo se dijelu ograničiti na posebnost koju pokazuje naročito

9 „Nel complesso ho procurato di rintracciare ed appianare le principali difficoltà che potrebbero scontrarvisi dagli Italiani, col riportare sempre gli esempi corrispondenti tradotti in ambe le lingue (Parčić 1878: VI).

10 Godine 1864. dužnost svećenika-lektora ili lektora-učitelja redovničke mladeži u Krku preuzima Dragutin Antun Parčić.

11 „La Grammatica espone le regole di ben parlare e di scrivere correttamente una lingua (Parčić 1878: 1)."

12 Autor tako nastavlja tradiciju svojih prethodnika A. Mažuranića i A. Vebera od kojega i preuzima hrvatske nazive.

Iako je Parčić gramatiku zapisao talijanskim jezikom, velik je broj naziva zapisao i hrvatskim jezikom. O Parčićevu jezikoslovnu nazivlju v. npr. Vlastelić 2011; Morić-Mohorovičić 2016; Morić-Mohorovičić - Vlastelić 2018.

13 U hrvatskome je jezikoslovlju predmet sintaktičkoga opisa do sredine 19. stoljeća bila sintagma, a distribucionalistički su opisi u starijim hrvatskim gramatikama svedeni na nevelik broj sintaktičkih pravila (npr. Bartol Kašić: 13; Ardelio Della Bella: 9). Nakon Ilirske slovnice Vjekoslava Babukića te Slovnice i Skladnje ilirskoga jezika za niže gimnazije (u daljnjem tekstu: Skladnja) Adolfa Vebera temeljna sintaktička jedinica postaje rečenica. 
hrvatski jezik, u odnosu na talijanski, izostavljajući ono što je zajedničko u oba jezika"14.

Iako je u predgovoru najavio da je „u sintaksi slijedio drugačiji red $\mathrm{u}$ odnosu na druge gramatičare"15, analizom je utvrđeno da mu je glavnim uzorom bila Slovnica Adolfa Vebera, njegova suvremenika i nositelja misli zagrebačke filološke škole, kojoj je i pripadao ${ }^{16}$.

Poput Vebera, Parčić sintaksu naziva skladnjom te je klasificira u tri dijela: Slaganje, Poraba i djelovanje te Poredanje rieči. Zbog ograničena ćemo prostora u ovom radu predstaviti prvi dio Parčićeva nauka.

Slaganje „tumači način na koji se u rečenici moraju spojiti i slagati u završetcima različiti fleksibilni dijelovi, vodeći računa o rodu, broju, padežu i licu"17. Napominje tako autor da kod slaganja „kao sintaktičkoga odnosa valja voditi računa o morfološkim kategorijama roda, broja i padeža" (Stolac - Vlastelić 2005: 5). Građa se pritom dijeli u četiri potpoglavlja: subjekt i predikat; atribut; objekt; zamjenice. ${ }^{18}$ Već je iz ovakve podjele razvidan Parčićev pristup sintaksi hrvatskoga jezika. Naime, autor se u sintaktičkome opisu služi i morfološkim nazivljem. Štoviše, u Porabi i djelovanju građa je klasificirana prema vrsti riječi (Imenice, Pridjevi, Zamjenice, Broj, Glagol, Prijedlozi, Uzvici). Iz navedenoga se dade zaključiti da Parčić sintaktičke odnose opisuje pomoću opisa odnosa među vrstama riječi.

14 „In questo Tratatto ci limiteremo di preferenza e quanto presenta di particolare la lingua slava in confronto all'italiana, omettendo ciò, che v'ha di comune nelle due lingue" (Parčić 1878: 129).

Ipak, autor u sintaktički dio unosi i napomene zajedničke obama jezicima, o čemu će riječi biti u nastavku integralnoga teksta.

15 „nella Sintassi ho seguito un'ordine alquanto diverso da quello degli altri grammatici” (Parčić 1878: VI).

16 Usp. Morić-Mohorovičić 2014.

17 „La Concordanza espone il modo come debbano unirsi in proposizione e corrispondersi nelle desinenze le diverse parti flessibili, avuto riguardo al genere, al numero, al caso, ed alla persona" (Parčić 1878: 129).

Dok u Vebera Skladnja slaganja opisuje rečenicu, rečenične dijelove te odnose među njima, Parčić u dijelu Slaganje tek naznačuje subjekt, predikat, atribut i objekt te opisuje odnose među njima. Iako rečenicu ne uključuje u Slaganje, spominje pojam proste rečenice, ali je ne objašnjava.

18 U prvom izdanju Grammatice građa je podijeljena u pet potpoglavlja: subjekt i predikat; particip sa subjektom; atribut; objekt; zamjenice. U drugom je izdanju potpoglavlje particip sa subjektom uključeno u potpoglavlje subjekt i predikat. 
U vezi sa slaganjem predikata i subjekta, Parčić ih u izdanju Grammatice iz 1873. drži glavnim dijelovima rečenice koji „ne smiju nikad nedostajati”19 te uočava „jednu od značajki hrvatske sintakse - mogućnost da subjekt ne mora biti izrečen” (Stolac - Vlastelić 2005: 5), tj. da „se ponekad može i podrazumijevati" ${ }^{20}$. Predikat može biti glagolski i imenski, a subjekt je "obično stavljen u padež nominativ" ${ }^{21}$. Iznimka su narodne pjesme u kojima se „imenice muškoga roda /.../ zbog potrebe stiha nalaze također i u vokativu, npr. Divan čini Otmanović care, po imenu Memede Sultane"22. Time autor zaključuje osnovne činjenice o subjektu i predikatu, a njihovo slaganje pojašnjava u daljnjem tekstu.

„Imenski predikat /.../ slaže se sa subjektom u rodu, broju i padežu, npr. Brat je mio; Voće je sladokusno"23. Pritom na umu valja imati posebnost imenskoga predikata: „kada imenica dolazi u službi predikata, ona se /.../ može također nalaziti i u padežu instrumentalu, npr. On je bio učiteljem kad sam ja još djetetom bio" 24 . Pojašnjava tako Parčić jezičnu činjenicu koju ne uočavaju svi njegovi prethodnici, ${ }^{25}$ što ovisi i o književnojezičnome tipu koji je u gramatikama opisan (Stolac - Vlastelić 2005: 6). Iz definicije imenskoga predikata proizlazi da autor u imenski dio imenskoga predikata ubraja tek

19 „non possono mai mancare queste dui parti essenziali” (Parčić 1873: 118).

U drugome izdanju svoje Grammatice Parčić izostavlja navedenu napomenu.

20 „può talora essere anche sottinteso” (Parčić 1873: 118).

U drugome izdanju Grammatice Parčić izostavlja navedenu napomenu.

21 „è posto ordinariamente al Nominativo” (Parčić 1878: 130).

22 „nomi maschili /.../per comodità di verso, trovansi posti anche al vocativo: Divan čini Otomanović care, po imenu Memede Sultane (Tien consiglio lo zar Otm. per nome M. S.)" (Parčić 1878: 130).

23 „Il predicato nominale concorda col sno soggetto in genere, numero e caso: Brat je mio (il fratelo è caro); voće je sladokusno (il frutto è delicato)" (Parčić 1878: 130).

24 „quando è precisamente un sostantivo che fa da predicato, desso col verbo biti e co' preaccennati può stare anche al caso instrumentale: On je bio učiteljem kad sam ja još djetetom bio" (Parčić 1878: 130).

U prvome izdanju Grammatice primjer glasi: On je bio učiteljem kad sam ja bio djetetom.

25 Ovu je posebnost imenskoga predikata uočio i Veber. U Skladnji drži da „predikat može sa kopulom biti samo onda stajati u instrumentalu, ako bi se inače teško razumělo, što je subjekt, što li predikat" (Veber 2005: 14). U Slovnici odustaje od navedena pravila te smatra da između imenskoga dijela imenskoga predikata u nominativu i instrumentalu postoji značenjska razlika, u nominativu "znači slučajno svojstvo, kad li stoji u instrumentalu, znači bitno svojstvo, po čem predikat postaje jednako širok kano i subjekt" (Veber 1871: 96). 
imenice ( $u$ nominativu i instrumentalu), pridjeve te poneke zamjenice i brojeve. ${ }^{26}$

Glagolski predikat klasificiran je u dvije skupine: „glagoli u kojem jednostavnom vremenu, a tada se slažu sa subjektom u broju i licu"27, npr. Otac piše te glagoli „u kojem složenom vremenu (pomoćni glagol biti i particip)" ${ }^{28}$, npr. Tvoje su me rieči raztužile. Iz navedenoga se dade zaključiti da Parčić u složenih vremena izostavlja tvorbu futura koji tumači u morfološkome dijelu Grammatice te u drugome dijelu svojega sintaktičkog nauka: Porabi i djelovanju (npr. činit ću, ću doći). ${ }^{29}$

Iz navedenoga je razvidno da je Parčić prednost u tumačenju predikata dao imenskome predikatu, čija je pojavnost rjeđa. Takvim se zapisom pokazao dobrim didaktičarom, koji prvenstvo u tumačenju daje onim primjerima u kojima bi njegovi učenici mogli griješiti.

U prvom izdanju Grammatice navodi da „s jednim zbirnim subjektom, kao vojska, narod, puk, cvieće, kamenje itd. kopula ili glagolski predikat ostaje u jednini" ${ }^{30}$ : Vojska se krenu. ${ }^{31} \mathrm{U}$ drugome je izdanju navedeno pravilo skratio i stavio u bilješku: „/.../ zbirne imenice koje odgovaraju talijanskim, npr. vojska, narod, puk, cvieće, kamenje i sl. /.../ slažu se jednako kao u talijanskome jeziku"32.

26 U službi imenskoga dijela imenskoga predikata mogu dolaziti imenice (u nominativu i instrumentalu), pridjevi, zamjenice, brojevi, prilozi, prijedložno-padežni izrazi, konstrukcije s besprijedložnim genitivom, konstrukcije s česticom kao ili kao i. Usp. npr. Silić - Pranjković 2007: 289-290.

27 „in qualcuno de'suoi tempi semplici, ed allora accorda col soggettoin numero e persona” (Parčić 1878: 131).

28 „in uno de tempi composti (cioè dell'ausiliare biti e del participio proprio)” (Parčić 1878: 31). Klasifikacija glagolskoga predikata izostaje u prvom izdanju Grammatice.

29 U prvome izdanju Grammatice izostaje klasifikacija glagolskoga predikata, ali iz primjera se dade pretpostaviti da Parčić u glagolski predikat ne ubraja oblike futura: Otac piše; Mi smo radili; Zastave se viju. Usp. Parčić 1873: 118.

30 „,con un soggetto collettivo, come vojska, narod, puk, cvieće, kamenje ecc. la copula, o il predicato verbale rimane al singolare" (Parčić 1873: 118-119).

31 Sličan naputak s primjerom zapisuje i Veber: „Kada je subjektom skupno ime, predikat stoji u jednobroju; n. p. Vojska se kretje” (Veber 1871: 96).

32 „/.../ collettivi corrispondenti ai collettivi italiani, come vojska (l'esercito), narod (nazione), puk (popolo), ecc. e cvieće, kamenje e simili vogliono la concordanza come in italiano" (Parčić 1878: 131). 
Zbirne imenice koje označavaju „mlade životinje sa završetkom na ad: telad, jagnjad itd., ipak traže kopulu ili predikat u množini /.../ npr. Telad su izišla na pašu"33. Rješenje je to koje pokazuje da je Parčić u ponekim primjerima zbirnih imenica pravilo prilagodio slaganju po smislu.

Parčić prepoznaje i mogućnost izricanja partitivnosti: „subjekt u neodređenome ili partitivnome liku (koji je u genitivu): Došlo je na pazar konja i volova" ${ }^{34}$. Preciznije je to tumačenje partitivnosti od onoga u izdanju Grammatice iz 1873.: „Ova se imenica (sila, šaka, množtvo, jato i sl., op. B. M. M.) ponekad podrazumijeva i pojavljuje se samo u genitivu (slaže se s oni), te zamjenjuje subjekt, npr. Došlo je na pazar konja i volova. podrazumijeva množivo, izobila"35.

Po uzoru na Vebera ${ }^{36}$ Parčić zapisuje da „kada je subjekt imenica koja znači množinu, kvantitetu kao: sila, šaka, većina i sl. ${ }^{37}, /$.../ npr. Sila ljudi došlo je na sastanak, a većina ih je protuglasovala"38, kopula ili glagolski predikat „uvijek ostaje u trećem licu jednine i particip u srednjem rodu” ${ }^{39}$. U prvom izdanju Grammatice navodi da „bi se /.../ moglo također oblikovati i na talijanski način, tj. slažući glagol sa subjektom, kao u navedenim primjerima: Većina je protuglasovala. Mnoge su godine prošle"40. Oba rješenja

33 „animali giovani in ad, come telad, jagnjad ecc. vogliono la copula o il predicato al plurale (il participio però resta al singolare feminile, p. es. /.../ telad su izišla na pašu (i vitelli sono usciti al pascolo)" (Parčić 1878: 131).

34 „un soggetto espresso in modo indeterminato o partitivo (che sta al genitivo): Došlo je na pazar konja i volova (sono venuti al mercato de'cavalli e de' bovi)" (Parčić 1878: 132).

35 „Questo sostantivo talor si sottintende ed apparisce solamento un genitivo (retto da essi), che fa veci di soggetto, come: Došlo je na pazar konja i volova sottint. množivo, izobila (sono venuti al mercato de'cavalli e de' bovi)" (Parčić 1873: 119).

36 „Kada je subjektom samostavnik, koji neizvěstan broj naznačuje, onda predikat stoji u srednjem spolu jednobroja, a glagolj 3. os. jednob.; ovakovi jesu: sila, množtvo (šaka, kup, stado, četa, broj, čreda, jato, sbor, komad, križka, kus, mèrva, većina, itd. (Veber 2005: 34)) /.../: Sila je ljudi bolestno (Veber 1871: 91).

37 Parčić u prvom izdanju Grammatice (1873) navodi primjere: sila, šaka, množtvo, jato. Usp. Parčić 1873: 118.

38 „soggetto de' nomi esprimenti moltitudine, quantità, come sila, šaka, većina ecc. /.../ Sila ljudi došlo je na sastanak, a većina ih je protuglasovala (molte persone son venute al convegno e la maggioranza ne ha votato contro)" (Parčić 1878: 132).

39 „resta nella terza persona del singolare ed il participio al. nom. neutro” (Parčić 1878: 132).

40 „suesposti si potrebbe conformare anche al modo italiano, accordando cioè il verbo col soggetto, come negli esemp addotti: Većina je protuglasovala. Mnoge su godine prošle" (Parčić 1873: 119). 
dopušta i Veber ${ }^{41}$. Međutim, u Parčića ostaje nejasno na što se odnosi slaganje glagola sa subjektom. Naime, Veber naznačuje da se u spomenutim primjerima predikat može slagati „budi s likom, budi sa značenjem subjekta" (Veber 1871: 97) navodeći tako slaganje po obliku te slaganje po smislu. Parčić takvu podjelu od Vebera ne preuzima pa pribjegava nejasnim rješenjima, što svakako otežava učenje jezika (na početnome stupnju).

Dvojno se rješenje dopušta i u niječnom bezličnom načinu: „Niječan glagolski predikat, osobito glagola nebiti, neimati, može se ne slagati sa svojim subjektom, i u tom se slučaju upotrebljava bezlični način, kao: Neima ili nije gospodara kod kuće; Nestalo nam je ognja i vode. /.../ Također ne nedostaju suprotni primjeri, s obzirom da se može reći: Gospodar nije kod kuće.; Oganj i voda su nam nestali., ali prvi je način pravilniji" ${ }^{2}$. U izdanju iz 1878. Parčić navodi da je u navedenim primjerima „subjekt u genitivu” ${ }^{43}$. Potonji su primjeri potvrda da autor unutar književnoga jezika razlikuje pojmove neutralno - stilogeno pa genitiv drži neutralnom oznakom te ga normira kao „pravilniji”, a nominativ stilogenom oznakom.

S tim je u vezi i Parčićev nauk o mogućnosti izbora između akuzativa i genitiva koji se odnosi na slavenski genitiv „s glagolima u negaciji”44. Autor tako tumači da se akuzativ u zanijekanim rečenicama „može nalaziti, ali vrlo rijetko" 45 . Opis slučajeva u kojima se javlja akuzativ „vrlo je nejasan i svakako ne govori o stilističkoj biti razlike između genitiva i akuzativa u zanijekanoj rečenici” (Stolac - Vlastelić 2005: 8): „1. Kada se slaže s drugim glagolom koji se nalazi u infinitivu: Nećeš dlanom zakloniti sunce; 2 . Kada je suprotstavljen drugom potvrdnom glagolu i slijedi ga: Vode babu, kad nemaju djevojku. Može mu i prethoditi: Tko nema glave ima pete"46.

\footnotetext{
41 „Sa svimi ovimi rěčmi (usp. bilješku 36, op. B. M. M.) /.../ može se predikat u svačem slagati budi s formom, budi sa značenjem subjekta" (Veber 1871: 91).

42 „Il predicato verbale negativo, specialmente de' verbi nebiti, neimati (non essere), può non accordare col suo soggetto, ed in tal caso viene usato in modo impersonale, come: Neima o nije gospodara kod kuće (il padrone non c' è in casa); Nestalo nam je ognja i vode (ci mancò il fuoco e l' acqua). /.../ Non macano esempj anche del contrario, potendosi dire: Gospodar nije kod kuće; Oganj i voda su nam nestali, però la prima maniera è più propria" (Parčić 1873: 120).

43 „sogetto sta a genitivo” (Parčić 1878: 132).

44 „verbi negativi” (Parčić 1878: 134).

45 „può stare, ma assai di raro” (Parčić 1878: 134).

46 „1. Quando è retto da un' altro verbo che trovasi all' infinito: Nećeš dlanom zakloniti sunce (non potrai nascondere il sole colla palma di mano).
} 
Da se Parčić oslanja na znanja koja su njegovi učenici stekli u talijanskome jeziku, svjedoči i sljedeće pravilo iz prvoga izdanja Grammatice: „Ako subjekt zamjenjuje pokazna zamjenica koja se pomoću glagola biti spaja s imenicom, onda ona uvijek ostaje u jednini srednjega roda, premda je u talijanskome u potpunom skladu, npr. Ovo je moj brat.; Je li ono vaša kuća?; To su moje knjige" 47 .

D. Stolac i A. Vlastelić zaključile su da „poznavatelji kongruencijskih odnosa u hrvatskom jeziku /.../ mogu utvrditi da sve Parčićeve (kongruencijske, op. B. M. M.) zamjedbe nisu uvijek bile uspješne" (Stolac Vlastelić 2005: 7). Tako autor dobro navodi glavno kongruencijsko pravilo: „S više subjekata različitoga roda i broja, predikat se nalazi u množini, slaže se radije s muškim nego ženskim rodom, te sa ženskim radije nego srednjim rodom: Otac i mati su otišli; Brat, sestra i nevjesta došli su mi u pohode"48. U bilješci dodaje da se „mogu naći primjeri u kojima predikat ostaje također u jednini i slaže se s najbližom imenicom, posebno kada su subjekti nežive stvari, npr. Crkva i škola je potrebna” 49 , a u primjerima u kojima je „predikat rastavljiv, tj. ako se sastoji od pomoćnoga glagola i participa, prvi se slaže s prvim subjektom, a drugi s drugim, npr. Dvorovi su i kuća popravljena"50. Međutim, valja imati na umu da Parčićeva zapažanja nisu bila novost.

2. Quando stà in opposizione ad un' altro verbo affermativo, e lo segue: Vode babu, kad nemaju djevojku (prendono in isposa una vecchia, quando non v' è fanciulla). Non già se lo precede: Tko nema glave ima pete (chi si dimentica deve rifar la strada)" (Parčić 1878: 134).

47 „Se fa veci di soggetto un pronome dimonstrativo, che mediante il verbo biti (essere) si unisce ad un sostantivo, esso rimane sempre al neutro singolare, quantunque in italiano faccia un perfetto accordo, p.s. Ovo je moj brat (questo è mio fratello); Je li ono vaša kuća? (è quella la vostra casa?); To su moje knjige (codesti sono i miei libri)” (Parčić 1873: 120).

48 „Con più soggetti di diverso genere o numero il predicato sta al plurale ed accorda col maschile a preferenza del feminile, e col feminile a preferenza del neutro: Otac i mati su otišli (il padre e la madre sono partiti); Brat, sestra i nevjesta došli su mi u pohode (sono venuti a visitarmi il fratello, la sorella e la cognata)" (Parčić 1878: 133). U prvome izdanju Grammatice (1873.) Parčić navodi i primjer Kriepost i mudrost obogaćuju čovjeka. Ipak, uočava svoju pogrešku pa navedeni primjer ne uvrštava u drugo izdanje.

49 „Trovansi degli esempj, in cui il predicato rimane anche al singolare ed accorda col nome più vicino, specialmente quando i soggetti sono di case inanimate, p. es. Crkva i škola je potrebna (la Chiesa e la scuola sono necessarie)" (Parčić 1878: 133).

50 „Se il predicato è separibile, cioè se consta dell' ausiliare e del participio, quello può accordare con un soggetto e questo coll' altro, p. es. Dvorovi su i kuća popravljena (i cortili e la casa sono allegati)" (Parčić 1878: 133). 
Glavnim mu je uzorom u pisanju pravila o kongruenciji bio Veber ${ }^{51}$. Parčić je nekritički preuzimao Veberova rješenja pa nije uočio poneke specifičnosti. Tako, primjerice, Veber piše da se „kod osobah i životinjah slaže kadšto predikat s jednim ili najbližim, ili najvažnijim subjektom; n. p. Zapovědnikje i Marula oslobodila grad od propasti. Judita se je i Holoferne sastala na razkrižju" 52 (Veber 1871: 98). Primjeri koje Veber zapisuje pripadaju književnom stilu, što Parčić ne zamjećuje. Novost je u odnosu na Veberov nauk Parčićeva tvrdnja da se „predikat u množini slaže /.../ sa ženskim radije nego srednjim rodom"53. S obzirom na to da je to jedino kongruencijsko pravilo koje Parčić ne oprimjeruje, može se pretpostaviti da autor nije bio siguran u njegovu ispravnost.

U obraćanju „osobi sa štovanjem (bilo da je muška, ili ženska) sa subjektom $V i$, bilo da je izričit, bilo da se podrazumijeva, particip se stavlja u množinu muškog roda, kao: Vi ste gospodine, jutros uranili.; Jeste li, gospojo, od mala došli?" ${ }^{4}$. Iako je Grammatica vrijedan izvor zapisa s terena s kraja 19. stoljeća, Parčić ne zapisuje Veberovu Opazku u kojoj se pojašnjava da se „u Primorju metje kopula jesam u plural, ali predikat, bio glagolj ili ime, stoji u singularu onoga spola, koji se pod vi razuměva; n. p. Što ste (vi) rekao? Što ste (vi) rekla?” (Veber 1871: 97). Kao rođeni Krčanin, Parčić je za tu čakavsku oznaku svakako znao. Ipak je u Grammaticu, koja opisuje književni jezik temeljen na štokavskome sustavu, ne uvrštava.

Autor uočava sintaktičku razliku između talijanskoga i hrvatskoga jezika: „u vremenima složenim pomoću pomoćnoga glagola i participa vlastitoga glagola, s participom se postupa kao da je predikativna dopuna,

51 Usp. npr. „Ako su spojeni subjekti istoga spola: mužkoga, ili ženskoga, predikat uzima isti spol plurala; ako li su ili istoga srednjega, ili poměšana s mužkim, predikat stoji u mužkom spolu plurala. /.../ slaže se kadšto predikat s jednim ili najbližim, ili najvažnijim subjektom; n. p. Zapovědnik je i Marula oslobodila grad od propasti. /.../ Kad se predikat oddvoji , sbude se kadšto, da se jedna polovica složi s jednim, a druga s drugim od spojenih subjektah; n. p. Ljudi su i pèrtljaga zarobljena. Mačevi su i cělo oružje polomljeno” (Veber 1871: 98).

52 U Skladnji Veber iz naputka izostavlja osobe pa piše „Kod životinjah /.../” (Veber 2005: 17). Dokaz je to da je Veberu predložak bila Veberova Slovnica, a ne Skladnja, što i sam priznaje u predgovoru.

53 „il predicato sta al plurale ed accorda /.../ col feminile a preferenza del neutro” (Parčić 1878: 133).

54 „persona di riguardo (sia maschio che femina) col soggetto Vi espresso o sottinteso, il participio si pone al plurale maschile: Vi ste gospodine, jutros uranili. (Ella signore se èalzato per tempo); Jeste li, gospojo, od mala došli? (È Ella, signora, arrivata da poco?)” (Parčić 1878: 131). 
stoga se sa svojim subjektom slaže u rodu i broju; dok u talijanskom s pomoćnim glagolom imati particip uvijek ostaje u jednini, npr. Mi smo prijeli.; Otac i mati su mi to naredili" 55 . Ovakvim se zapisom autor pokazuje dobrim didaktičarom, svjesnim da bi u takvim primjerima učenici školovani na talijanskome jeziku mogli najčešće griješiti u hrvatskoj sintaksi.

Atribut Parčić dijeli na epitet koji se „u obliku pridjeva ili participa, bilo da se odnosi na jednu imenicu, bilo da se istovremeno odnosi na više različitih imenica, poštujući slaganje, upotrebljava na sličan način kao u talijanskome jeziku” ${ }^{\prime 6}$ te na apoziciju koja se „predstavljena od jedne imenice ili također od jedne cijele rečenice, mora slagati barem u padežu s imenicom na koju se odnosi, npr. Sveti Petar sjede u Rimu, središtu izobraženoga

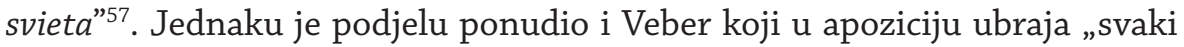
samostavnik, koji se u istom padežu dodaje subjektu; i svaki pridavnik, koji se dodaje subjektu /.../ ter se neproteže s njim jednako na glagolj” (Veber 1871: 94). Do izjednačavanja atributa i epiteta u oba autora dolazi „zbog visoke čestotnosti uporabe sročnoga atributa izraženoga pridjevom te stilske funkcije epiteta kao ukrasnoga pridjeva u književnome jeziku" (Stolac - Vlastelić 2005: 7). Definiranje apozicije kao vrste atributa „na tragu je suvremenoga poimanja atribucije kao preoblike rečeničnoga ustrojstva" (Stolac - Vlastelić 2005: 7). Pritom valja napomenuti da su Parčićeva definicija te primjer apozicije uspjeliji negoli u Vebera. Naime, Parčić za oprimjerenje slaganja apozicije $s$ imenicom izabire imenice različitih rodova (Rim : središte). Veber uvrštava primjere potpune sročnosti tipa Ciceron : konzul u kojima se apozicija s imenicom uz koju stoji slaže u rodu, broju i padežu. Veber u apoziciju ubraja i pridjeve koji se „neprotežu (sa subjektom,

55 „Ne'tempi composti mediante l'ansiliare ed il participio del verbo proprio, questo participio trattasi come fosse un complemento predicativo, quindi concorda col suo soggetto in genere e numero; mentre nell'italiano coll'ausiliare avere il participio sta sempre al singolare, p. es. Mi smo prijeli (noi abbiamo ricevuto); Otac i mati su mi to naredili (il padre e la madre me lo hanno ordinato" (Parčić 1873: 121).

Navedeno pravilo Parčić ne uvrštava u drugo izdanje Grammatice (1878.).

56 „il forma di aggettivoo participio, sia che si riferisca ad un sostantivo, sia che riguardi contemporaneamente più sostantivi distinti, rispetto alla concordanza usasi in modo analogo a quello della lingua italiana" (Parčić 1878: 133).

57 „rappresentato da un sostantivo o anche da un'intera proposizione, deve accordare almeno nel caso col sostantivo a cui si riferisce, p. es. Sveti Petar sjede u Rimu, središtu izobraženoga svieta (S. Pietro fissò la sede in Roma, centro dell' orbe civilizzato)" (Parčić 1878: 133). 
op. B. M. M.) jednako na glagolj” (Veber 1871: 94), npr. Petar veliki sagradio je Petrograd; Chrysostom zlatousti napisao je mnogo knjigah. Iz navedenoga se dade zaključiti da su Parčićeva promišljanja o apoziciji bliža suvremenom jezikoslovlju. ${ }^{58}$

Objekt proširuje jednostavnu rečenicu sastavljenu od subjekta i predikata: „Jedna se prosta rečenica proširuje vrlo često također s objektom, što je točno ona osoba ili stvar na koju pada radnja glagola"59. U prvom pravilu Parčić tumači semantičku razliku koja se može ostvariti izborom objekta u akuzativu ili u genitivu, koji poznaje i talijanski jezik, npr. Daj mi knjigu : Dajte mi kruha. U prvom se slučaju radnja „proširuje na cijeli objekt”60, a u drugome „samo na njegov dio"61. Dakako, u potonjem je primjeru riječ o partitivnom genitivu.

Glagolsku je dopunu u instrumentalu Parčić neprecizno pojasnio: „Ako je objekt popraćen imenskim atributom ili apozicijom, što se događa iza glagola fare (raditi, op. B. M. M.), leggere (čitati, op. B. M. M.), nominare (imenovati, op. B. M. M.), credere (vjerovati, op. B. M. M.), stimare (procijeniti, op. B. M. M.) i sličnima, ovaj se može slagati s njim, ali češće se stavlja u instrumental, iako mu u talijanskome prethode prijedlozi: $a$ (na, op. B. M. M.), per (za, op. B. M. M.), in (u, op. B. M. M.), npr. Izabrati koga kraljem.; Imenovati tajnikom"62. Pritom ne navodi slijed za + akuzativ, „premda ga jezik poznaje, a bio bi i jednostavniji talijanskim govornicima zbog postojanja istovrsne sintagme u talijanskome jeziku" (Stolac Vlastelić 2005: 8). I u pasivnoj konstrukciji Saul bi postavljen kraljem nad Izraelom Parčić drži da je imenica u instrumentalu u službi objekta. U većini

58 Iako ga Parčić ne spominje, moguć je izostanak sročnosti i u padežu, što je „osobito često onda kad apozicija stoji ispred vlastite imenice čije primarno značenje nije u skladu ili nije tipično za ono što se njome označuje, nego je takva imenica primarno vlastito ime za što drugo" (Pranjković 2003: 39). O apoziciji usp. npr. Težak - Babić 1992: 208-211; Barić i sur. 1997: 536-537; Katičić 2002: 478-481; Silić - Pranjković 2007: 313-314.

59 „Una proposizione semplice si amplia assai di frequento anche coll' oggetto, ch' e propriamente quella persona o cosa su cui cade l'azione del verbo" (Parčić 1878: 134).

60 „s'estende alla totalità di un oggetto” (Parčić 1878: 134).

61 „soltanto ad una porzione del medesimo” (Parčić 1878: 134).

62 „Se l' oggetto è accompagnato da un' attributo nominale, o da un' apposizione, ciò che ha luogo dietro i verbi fare, leggere, nominare, credere, stimare, e simili, questo può concordare con esso; ma più di frequente ponesi all' Istrumentale, anche se in Italiano sia preceduto dalle preposizioni a, per, in, p. es. Izabrati koga kraljem (eleggere un re); Imenovati tajnikom (nominare a segretario)" (Parčić 1878: 134). 
su suvremenih jezičnih priručnika spomenute konstrukcije u instrumentalu označene kao predikatni proširci ${ }^{63}$.

U vezi sa zamjenicama, valja napomenuti da Parčić posebnu pažnju posvećuje uporabi odnosne zamjenice $k o j i^{64}$. U pojašnjenju kongruencijskih odnosa sa zamjenicom koji Parčić se oslanja na znanja koja su njegovi učenici usvojili u talijanskoj gramatici, npr. „Odnosna zamjenica koji, a, e, slaže se, kao i u talijanskome, u rodu i broju s imenicom na koju se odnosi" ${ }^{65}$. Poneke konstrukcije Parčić pojašnjava prevodeći talijanske izraze: „Talijanski izrazi colui che (onaj koji), quegli che (onaj koji), coloro (oni, one, ona), quali (koji) i sl. na hrvatskome jeziku mogu biti prevedeni jednom jedinom odnosnom zamjenicom koji, koja se i tada mora slagati u padežu s imenicom na koju se odnosi, npr. Koji ljudi zlo rade, kloni ih se"66. Iz navedenoga se dade zaključiti da je Parčić kao dobar učitelj svjestan sintaktičkih razlika između hrvatskoga i talijanskoga jezika i konstrukcija u kojima bi njegovi učenici, školovani na talijanskome jeziku, mogli griješiti u hrvatskome jeziku.

To je, u najkraćem, prikaz prvoga dijela Parčićeve sintakse. Iz njega se vidi da autor ima dobrih i prihvatljivih rješenja, primjerice tumačenje imenskoga predikata, partitivnosti, opis atributa, ali i nevelik broj nedorečenosti i nepreciznosti. To se posebno odnosi na neprecizna tumačenja i definicije te na kongruencijske zamjedbe. Također, valja napomenuti da iako mu je glavni uzor u pisanju Grammatice bio Veber, Parčić je svojim sintaktičkim opisom napravio korak unatrag u odnosu na Veberovu Skladnju i Slovnicu. Naime, Parčićeva je skladnja sintaksa sintagme - opisuje odnose unutar sintagmi, s malobrojnim napomenama o rečenici.

63 Usp. npr. Katičić 2002: 97-98; Silić - Pranjković 2007: 292.

Eugenija Barić i sur. takve konstrukcije definiraju kao neizravne objekte u instrumentalu (usp. Barić i sur 1997: 441-442).

64 U izdanju Grammatice iz 1873. izdvojena je i zamjenica što „koja se može koristiti umjesto koji” („che può usarsi invece di koji” (Parčić 1878: 135)).

65 „Il relativo koji, a, e accorda, come in italiano, in numero e persona col sostantivo, a cui si riferisce" (Parčić 1878: 135).

66 „Le espressioni italiane colui che, quegli che, coloro i quali e simili possono essere tradotte in islavo col solo relativo koji, ed allora questo deve accordare anche nel caso col sostantivo a cui si riferisce, p. es. Koji ljudi zlo rade, kani ih se (guardati da quelle persone, che operano male)" (Parčić 1878: 135). 


\section{Izvori}

Dragutin Antun Parčić (1873) Grammatica della lingua slava (illirica), Spiridione Artale, Zadar.

Dragutin Antun Parčić (1878) Grammatica della lingue slava (ilirica), Spiridione Artale, Zadar.

Adolfo Veber (2005) Skladnja ilirskoga jezika za niže gimnazije, Beč, 1859. (pretisak Instituta za hrvatski jezik i jezikoslovlje, Zagreb)

Adolfo Veber (1871) Slovnica hèrvatska za srednja učilišta, Zagreb.

\section{Literatura}

Anić, Vladimir (1993) „Dragutin Parčić kao hrvatski gramatičar”, Zadarska smotra, XLII, 3, 93-102.

Barić, Eugenija i sur. (1997) Hrvatska gramatika, II. promijenjeno izdanje, Školska knjiga, Zagreb.

Bolonić, Mihovil, Žic-Rokov, Ivan (1997) Otok Krk kroz vjekove, Kršćanska sadašnjost, Zagreb.

Bratulić, Josip i dr. (2015) Povijest hrvatskoga jezika, knj. 4, Croatica, Zagreb.

Gostl, Igor (1998) Dragutin Antun Parčić, Matica hrvatska, Zagreb.

Ham, Sanda (1998) Jezik zagrebačke filološke škole, Matica hrvatska, Osijek.

Ham, Sanda (2006) Povijest hrvatskih gramatika, Nakladni zavod Globus, Zagreb.

Katičić, Radoslav (1986) „Prva gramatika Adolfa Vebera Tkalčevića”, Filologija, 14, 161-170.

Katičić, Radoslav (2002) Sintaksa hrvatskoga književnog jezika, 3. poboljšano izdanje, Hrvatska akademija znanosti i umjetnosti - Nakladni zavod Globus, Zagreb.

Morić-Mohorovičić, Borana (2014) Gramatičar Dragutin Antun Parčić, doktorska disertacija, Filozofski fakultet Sveučilišta u Rijeci.

Morić-Mohorovičić, Borana (2016) „Parčićevo morfološko nazivlje u kontekstu morfološkoga nazivlja zagrebačke filološke škole", Fluminensia, 28, 1, 69-81.

Morić-Mohorovičić, Borana i Vlastelić, Anastazija (2018) „Morfološko nazivlje u gramatikama i rječnicima Dragutina Antuna Parčića", Zbornik u čast Mariji Turk, ur. Diana Stolac, Biblioteka časopisa Fluminensia, Rijeka, 229-243. 
Novak, Grga (1966) „Presjek kroz povijest grada Zadra”, Grad Zadar, presjek kroz povijest, Zadar, 7-76.

Pranjković, Ivo (1992) „Fonološki i sintaktički opisi u prvim slavonskim gramatikama”, Radovi Zavoda za slavensku gramatiku, 27, 123-135.

Pranjković, Ivo (2003) Hrvatski jezik 3, udžbenik za 3. razred gimnazije, 4. izdanje, Školska knjiga, Zagreb.

Pranjković, Ivo (2005) „Adolf Veber Tkalčević i njegova Skladnja”, pogovor u: Adolfo Weber, Skladnja ilirskoga jezika za niže gimnazije, Beč 1859. (pretisak: Institut za hrvatski jezik i jezikoslovlje, Zagreb), 197-229.

Silić, Josip i Pranjković, Ivo (2007) Gramatika hrvatskoga jezika za gimnazije i visoka učilišta, Školska knjiga, Zagreb.

Stolac, Diana (1998) „Sintaksa Adolfa Vebera Tkalčevića”, Riječki filološki dani 2, Filozofski fakultet, Rijeka, 81-88.

Stolac, Diana i Vlastelić, Anastazija (2005) „Sintaksa u Parčićevoj gramatici hrvatskoga jezika iz 1873. godine”, Fluminensia, 1, 1-11.

Tafra, Branka (1993) Gramatika u Hrvata i Vjekoslav Babukić, Matica hrvatska, Zagreb.

Tafra, Branka (2012) Prinosi povijesti hrvatskoga jezikoslovlja, Hrvatski studiji Sveučilišta u Zagrebu, Zagreb.

Težak, Stjepko i Babić, Stjepan (1992) Gramatika hrvatskoga jezika. Priručnik za osnovno jezično obrazovanje, 7. izdanje, Školska knjiga, Zagreb.

Vlastelić, Anastazija (2011) „Parčićevo sintaktičko nazivlje - u kontekstu sintaktičkoga nazivlja hrvatskih gramatika druge polovice 19. stoljeća”, Filologija, 56, 159-175.

Vranić, Silvana i Badurina, Lada (2017) Dragutin Antun Parčić - Marcel Kušar: Izabrani radovi i pisma, Stoljeća hrvatske književnost. Knj. 135, Zagreb. 


\section{SUMMARY}

Borana Morić-Mohorovičić

REMARKS ON THE SYNACTIC FEATURES DESCRIBED IN THE GRAMMATICA DELLA LINGUA SLAVA (ILLIRICA) BY DRAGUTIN ANTUN PARČIĆ ${ }^{*}$

Grammatica della lingua slava (illirica) was written in the Italian language, which was the official language in the $19^{\text {th }}$ century Dalmatia, where Parčić spent most of his life. The grammar is divided into two parts: rječoslovje (phonetics and phonology, morphology and word formation) and skladnja (syntax). The syntactic part is further divided into three parts: Slaganje (Agreement), Poraba i djelovanje (Usage and Function) and Poredanje rieči (Word Order). The paper analyses the first part of the Syntax - Agreement. Syntactic features described by Dragutin Antun Parčić are compared to those described by Veber in Skladnja ilirskoga jezika (1859) and Slovnica hèrvatska za srednja učilišta (1871). While Veber describes the sentence, its parts and relations between them, Parčić only defines the subject, predicate, attribute and object and describes the relations between them in the Agreement section. Although the level of the sentence is not included in the Agreement, Parčić mentions the term simple sentence without explaining it.

Key words: Dragutin Antun Parčić; Adolfo Veber; syntax; $19^{\text {th }}$ century

\footnotetext{
"This work has been fully supported in part by the University of Rijeka under the project number uniri-human-18-285.
} 